\title{
Elderly patients are at greater risk of cytopenia during antiviral therapy for hepatitis $\mathrm{C}$
}

\author{
CG Nudo MD, P Wong MD, N Hilzenrat MD, M Deschênes MD
}

\begin{abstract}
CG Nudo, P Wong, N Hilzenrat, M Deschênes. Elderly patients are at greater risk of cytopenia during antiviral therapy for hepatitis C. Can J Gastroenterol 2006;20(9):589-592.
\end{abstract}

The results of antiviral therapy for hepatitis $\mathrm{C}$ virus (HCV) have improved recently with the use of pegylated interferon (PEG-IFN)/ribavirin (RBV) combination therapy. At this point, most patients with chronic HCV remain untreated. Thus, it is anticipated that therapy will be more appealing and prescribed more broadly than in the past, including in patients considered marginal. AIM: To examine the effects of PEG-IFN-based antiviral therapy in elderly patients with chronic HCV.

METHODS: The charts of patients treated with chronic HCV were reviewed. Patients were defined as elderly if they were 60 years of age or older. The control group consisted of patients younger than 60 years of age who were matched to the treated elderly patients based on sex, treating physician, prescribed treatment and intended prescribed treatment duration. The data recorded included end of treatment response, sustained virological response (SVR), adverse events, dose modification and withdrawal of therapy.

RESULTS: Thirty of 147 (20.4\%) elderly patients attending a hepatitis $\mathrm{C}$ clinic were treated. The average age of the elderly patients was $65 \pm 4$ years. Forty-three per cent were men and $57 \%$ were women. Ten per cent received IFN monotherapy, 70\% received a combination of IFN/RBV therapy and $20 \%$ received a combination of PEG-IFN/RBV therapy. The overall response rates in the elderly patients compared with the younger patients was $46.7 \%$ versus $65.8 \%$ $(\mathrm{P}=0.11)$ for end of treatment response and $33.3 \%$ versus $51.2 \%$ $(\mathrm{P}=0.13)$ for SVR. The rate of dose modification was $50 \%$ in the elderly patients compared with $29 \%$ in the control group ( $\mathrm{P}=0.08)$. Therapy was discontinued in $53 \%$ of the elderly compared with $34 \%$ of younger patients $(\mathrm{P}=0.17)$. The younger patients reported more side effects than elderly patients; although, there were more laboratory abnormalities (anemia, thrombocytopenia and neutropenia) in the elderly patients during therapy than in the younger group ( 0.93 per patient versus 0.49 per patient, $\mathrm{P}=0.01$ ).

CONCLUSION: Elderly patients with chronic HCV can be treated successfully. However, they are more at risk to develop cytopenias while on treatment. In such patients, the close monitoring of blood counts is necessary. Larger studies are needed to confirm these findings and to determine whether SVR differs in this population.

Key Words: Cytopenia, Hepatitis C, Pegylated interferon therapy, Ribavirin therapy

\section{Les personnes âgées sont prédisposées à la cytopénie pendant le traitement antiviral de l'hépatite C}

CONTEXTE : L'arrivée récente de l'association de l'interféron (INF) pégylé (PEG) et de la ribavirine (RBV) a permis d'améliorer les résultats du traitement antiviral de l'hépatite C. Jusque là, la plupart des patients atteints d'hépatite $\mathrm{C}$ chronique n'étaient pas traités. Maintenant, on croit que le traitement sera plus attrayant et sera prescrit plus souvent que par le passé, entre autres, à des patients laissés en marge.

BUT : L'étude avait pour but d'examiner les effets du traitement antiviral composé d'INF-PEG et de RBV chez les personnes âgées atteintes d'hépatite $\mathrm{C}$ chronique.

MÉTHODE : Nous avons passé en revue les dossiers de patients traités pour une hépatite $\mathrm{C}$ chronique. Étaient considérés comme âgés les patients qui avaient 60 ans et plus. Le groupe témoin se composait de patients âgés de moins de 60 ans, qui ont été appariés à des patients âgés selon le sexe, le médecin traitant, le traitement prescrit et la durée prévue du traitement. Les données relevées portaient sur la réaction à la fin du traitement, la durée de la réaction virale, les effets indésirables, les modifications de la posologie et l'abandon du traitement.

RÉSULTATS : Trente patients âgés sur 147 (20,4 \%) fréquentant une clinique de traitement de l'hépatite $\mathrm{C}$ ont été traités. Ils avaient en moyenne $65 \pm 4$ ans; $43 \%$ d'entre eux étaient des hommes et $57 \%$, des femmes. Dix pour cent des patients ont reçu de l'INF seul; $70 \%$, de l'INF et de la RBV; 20\%, de l'INF-PEG et de la RBV. Les taux globaux de réaction chez les personnes âgées comparativement aux patients plus jeunes se sont établis à $46,7 \%$ contre $65,8 \%(\mathrm{P}=0,11)$ pour la réaction à la fin du traitement et à $33,3 \%$ contre $51,2 \%(\mathrm{P}=0,13)$ pour la durée de la réaction virale. Quant au taux de modification de la posologie, il était de $50 \%$ chez les personnes âgées et de $29 \%$ dans le groupe témoin $(\mathrm{P}=0,08)$. Par ailleurs, il y a eu abandon du traitement chez $53 \%$ des personnes âgées et $34 \%$ des jeunes $(\mathrm{P}=0,17)$. Enfin, les jeunes ont fait état de plus d'effets indésirables que les personnes âgées, mais ces dernières présentaient plus d'anomalies aux examens de laboratoire (anémie, thrombocytopénie et neutropénie) en cours de traitement que les patients plus jeunes $(0,93$ par patient contre 0,49 par patient; $\mathrm{P}=0,01)$.

CONCLUSIONS : L'hépatite $\mathrm{C}$ chronique peut se traiter avec succès chez les personnes âgées, mais elles sont plus susceptibles de présenter de la cytopénie en cours de traitement. Une surveillance étroite de la numération globulaire s'impose donc chez ces personnes. Enfin, il faudrait mener des études plus poussées pour confirmer les résultats obtenus et vérifier si la durée de la réaction virale varie selon les populations.

Department of Medicine, McGill University Health Centre, Montreal, Quebec

Correspondence: Dr Marc Deschênes, McGill University Health Centre, Liver Transplant Program, 687 avemie des Pins, Room 2.28, Montreal,

Quebec H3A 1A1.Telephone 514-843-1616, fax 514-843-1421, e-mail marc.deschenes@muhc.mcgill.ca

Received for publication June 16, 2005. Accepted January 16, 2006 
T is estimated that there are 170 million individuals infected with hepatitis $\mathrm{C}$ virus (HCV) worldwide (1). There have been recent improvements in antiviral therapy for $\mathrm{HCV}$, with the use of pegylated interferon (PEGIFN)/ribavirin (RBV) combination therapy. Despite these advances most patients with chronic HCV remain untreated. To date, large studies that have evaluated IFN therapy have typically had strict exclusion criteria (2-5). These studies often excluded elderly patients. In fact, the 1997 Consensus Development Conference Panel on the Management of Hepatitis C infection recommended that therapy be limited to adults, 18 to 60 years of age, who had compensated liver disease with elevated aminotransferase level and no comorbid conditions, except HIV infection (6). Elderly patients with HCV have been inadequately studied (7-12) and are often not treated $(13,14)$. The aim of the present study was to examine the results of IFN-based antiviral therapy in elderly patients with chronic HCV.

\section{METHODS}

The charts of patients treated for chronic HCV at Royal Victoria Hospital (Montreal, Quebec) and Jewish General Hospital (Montreal, Quebec) were reviewed. Patients were defined as elderly if they were 60 years or older. The elderly group was compared with control patients, younger than 60 years of age, who were attending and treated at the clinics. An attempt was made to match patients based on sex, treating physician, prescribed treatment and prescribed treatment duration. Patients with HIV coinfection were not included in the analysis. The data recorded included end of treatment response (ETR), sustained virological response (SVR), adverse events, dose modification and withdrawal of therapy. All patients begun therapy from October 1996 to September 2002. The choice of drug therapy (IFN monotherapy, IFN and RBV, or PEG-IFN and RBV) was based on the therapy that was available at the time of treatment initiation and the choice of the treating physician. The treating physician decided the prescribed treatment duration.

ETR was defined as a negative qualitative HCV RNA test using the polymerase chain reaction (PCR) at the end of therapy (HCV PCR, Roche Kit [USA]). SVR was defined as a negative HCV RNA test using PCR after 24 weeks of completion of therapy. Clinically significant anemia, thrombocytopenia and neutropenia were considered to have occurred if patients developed grade 2 or greater cytopenia as defined by the Common Toxicity Criteria of the National Cancer Institute (USA) (15). Treating physicians treated laboratory abnormalities and adverse events by reducing drug doses according to manufacturer's instructions or by discontinuing therapy.

\section{Statistical analysis}

Statistical analysis was performed using GraphPad Quickcals Software (GraphPad Software Inc, USA). The Fisher's exact test was used to compare the incidence of ETR, SVR, laboratory abnormality events, adverse events, incidence of dose modification and incidence of withdrawal of therapy between the two groups. Student's $t$ test was used to compare the mean laboratory values before and after therapy between the two groups. $\mathrm{P} \leq 0.05$ was considered statistically significant.

\section{RESULTS}

Table 1 lists the patient's baseline characteristics. There was no significant difference in baseline characteristics between the
TABLE 1

Baseline characteristics

\begin{tabular}{|c|c|c|c|}
\hline Characteristics & Age $<60$ years & Age $\geq 60$ years & $\mathbf{P}$ \\
\hline $\mathrm{n}$ & 41 & 30 & \\
\hline Male, $\mathrm{n}(\%)$ & $24(58.5)$ & $13(43.3)$ & 0.21 \\
\hline Female, n (\%) & $17(41.5)$ & $17(56.7)$ & \\
\hline Mean age, years & $44.5 \pm 8.7$ & $65.13 \pm 4.2$ & $<0.0001$ \\
\hline \multicolumn{4}{|l|}{ Treatment } \\
\hline Interferon & $1(2.4)$ & $3(10)$ & 0.3 \\
\hline Inferferon + RBV & $27(65.9)$ & $21(70)$ & 0.8 \\
\hline $\begin{array}{l}\text { Pegylated interferon } \\
+ \text { RBV }\end{array}$ & $13(31.7)$ & $6(20)$ & 0.29 \\
\hline Mean hemoglobin, g/L & $147 \pm 16.8$ & $139 \pm 12$ & 0.0105 \\
\hline Mean neutrophils, $\times 10^{9} / \mathrm{L}$ & $3.84 \pm 1.71$ & $3.35 \pm 1.32$ & 0.097 \\
\hline Mean platelets, $\times 10^{9} / \mathrm{L}$ & $211 \pm 87$ & $155 \pm 75$ & 0.0042 \\
\hline \multicolumn{4}{|l|}{ Pathology, n (\%) } \\
\hline Biopsied & $39(95.1)$ & $27(90.0)$ & 0.64 \\
\hline Stage 0 & $2(4.9)$ & $0(0.00)$ & 0.51 \\
\hline Stage 1 & $2(4.9)$ & $1(3.3)$ & 1.00 \\
\hline Stage 2 & $13(28)$ & $1(3.3)$ & 0.003 \\
\hline Stage 3 & $10(24.4)$ & $13(43.3)$ & 0.12 \\
\hline Stage 4 & $12(29.3)$ & $9(30.0)$ & 1.00 \\
\hline Unknown & $0(0.00)$ & $3(10.0)$ & 0.07 \\
\hline \multicolumn{4}{|l|}{ Genotype, n (\%) } \\
\hline 1 & $18(43.9)$ & $8(26.7)$ & 0.21 \\
\hline 2 & $4(9.8)$ & $8(26.7)$ & 0.11 \\
\hline 3 & $4(9.8)$ & $0(0.00)$ & 0.13 \\
\hline 4 & $2(4.9)$ & $2(6.7)$ & 1.00 \\
\hline Unknown & $13(31.7)$ & $12(40)$ & 0.62 \\
\hline \multicolumn{4}{|l|}{ Prescribed duration, n (\%) } \\
\hline 24 weeks & $5(12.2)$ & $8(26.7)$ & 0.12 \\
\hline 48 weeks & $36(87.8)$ & $22(73.3)$ & \\
\hline
\end{tabular}

RBV Ribavirin

two groups except for age and lower hemoglobin and platelet levels in the elderly group. A higher proportion of young patients had stage 2 fibrosis or equivalent (16-18). There was no difference in the proportion of elderly patients with stage 3 and 4 fibrosis compared with the young group (73.3\% versus $53.7 \%, \mathrm{P}=0.14)$. There was no difference in treatment drugs and viral genotype between the elderly and young group.

Of all patients attending the HCV clinics, 20\% of the elderly patients and $33 \%$ of young patients were treated. Five physicians were involved in the treatment of the patients in the HCV clinics. There was no difference in distribution of patients among physicians. The first physician treated five young and five elderly patients, the second physician treated six young and four elderly, the third physician treated seven young and six elderly, the fourth physician treated 18 young and 13 elderly and the fifth physician treated five young and two elderly. Of these 30 elderly patients, $10 \%$ received IFN monotherapy, $70 \%$ received a combination of IFN/RBV therapy and 20\% received a combination of PEGIFN/RBV therapy.

The 30 elderly patients were compared with 41 young control patients. There was no significant difference in ETR (46.7\% versus $65.8 \%, \mathrm{P}=0.11$ ) and SVR (33.3\% versus $51.2 \%$, $\mathrm{P}=0.13$ ) between the two groups.

The rate of early termination of therapy in the elderly group was $53.3 \%$ and it was $34.1 \%$ in the young group $(\mathrm{P}=0.17)$. Adverse events were the most common reason for discontinuing 
TABLE 2

Completion of therapy and dose modification

\begin{tabular}{lccc}
\hline Outcomes & $\begin{array}{c}\text { Age }<\mathbf{6 0} \text { years } \\
\mathbf{n}(\%)\end{array}$ & $\begin{array}{c}\text { Age } \geq \mathbf{6 0} \text { years } \\
\mathbf{n}(\%)\end{array}$ & $\mathbf{P}$ \\
\hline Therapy stopped & $14(34.1)$ & $16(53.3)$ & NS \\
No response & $5(12.2)$ & $2(6.7)$ & NS \\
Adverse event & $5(12.2)$ & $9(30)$ & NS \\
Laboratory abnormalities & $3(7.3)$ & $5(16.7)$ & NS \\
Other & $3(7.3)$ & $3(10)$ & NS \\
Unknown & $2(4.9)$ & $0(0)$ & NS \\
Dose modification & $12(29.3)$ & $15(50)$ & NS \\
Increased & $0(0)$ & $2(6.7)$ & NS \\
Decreased & $12(29.3)$ & $13(43.3)$ & NS \\
Adverse event & $5(12.2)$ & $3(10)$ & NS \\
Laboratory abnormalities & $7(6)$ & $12(40)$ & 0.031 \\
Other & $0(0)$ & $2(6.7)$ & NS \\
\hline
\end{tabular}

NS Not significant

therapy (Table 2). The rate of dose reduction of therapy in the elderly group was $43.3 \%$ compared with $29.3 \%$ in the young group. The elderly had a significantly higher rate of dose reduction of therapy, $40 \%$ versus $6 \%(\mathrm{P}=0.031)$, due to laboratory abnormalities (anemia, thrombocytopenia and neutropenia). None of the physicians used growth factors to treat cytopenias.

All patients reported common adverse events (Table 3), although the younger group reported an overall higher rate of events than the elderly group (4.46 events per patient versus 2.9 events per patient, $\mathrm{P}<0.001)$. A significantly higher number of younger patients reported depression, myalgias and irritability. There were no adverse cardiovascular events reported.

Both treatment groups had significant and similar drops in blood counts with therapy. The mean drops in blood counts were $31.6 \mathrm{~g} / \mathrm{L}$ and $31 \mathrm{~g} / \mathrm{L}$ for hemoglobin, $2.0 \times 10^{9} / \mathrm{L}$ and $1.6 \times 10^{9} / \mathrm{L}$ for neutrophils, and $47 \times 10^{9} / \mathrm{L}$ and $36 \times 10^{9} / \mathrm{L}$ for platelets, for the group younger than 60 years and the group 60 years or older, respectively (Table 4 ). Although no young patients developed grade 2 or higher thrombocytopenia, $10 \%$ of the elderly patients developed grade $2\left(50 \times 10^{9} / \mathrm{L}\right.$ to $\left.74 \times 10^{9} / \mathrm{L}\right)$ and grade $3\left(10 \times 10^{9} / \mathrm{L}\right.$ to $\left.49 \times 10^{9} / \mathrm{L}\right)$ thrombocytopenia with therapy.

Fifteen per cent of young patients and 30\% of elderly patients developed grade $2(80 \mathrm{~g} / \mathrm{L}$ to $99 \mathrm{~g} / \mathrm{L})$ anemia with therapy. Seventeen per cent of young patients developed grade $2\left(1.0 \times 10^{9} / \mathrm{L}\right.$ to $\left.1.4 \times 10^{9} / \mathrm{L}\right)$ and grade $3\left(0.5 \times 10^{9} / \mathrm{L}\right.$ to $0.9 \times 10^{9} / \mathrm{L}$ ) neutropenia with therapy, while $16.7 \%$ and $26.7 \%$ of the elderly developed grade 2 and 3 neutropenia, respectively.

The elderly group had a significantly higher overall rate of laboratory abnormalities than the younger group $(0.93$ events per patient versus 0.488 events per patient, $\mathrm{P}=0.01$ ).

\section{DISCUSSION}

In the present comparison of young (younger than 60 years) and elderly (60 years or older) patients treated with IFN-based therapy for $\mathrm{HCV}$, we found that elderly patients with chronic HCV can be treated successfully. The elderly patients tolerated therapy well and reported fewer side effects than the younger patients. However, they were at greater risk for developing cytopenias while on treatment.

The elderly patients had a trend toward a higher rate of premature discontinuation of therapy, which was not statistically
TABLE 3

Reported adverse events/symptoms

\begin{tabular}{lccc}
\hline $\begin{array}{l}\text { Symptoms and } \\
\text { events }\end{array}$ & $\begin{array}{c}\text { Age }<\mathbf{6 0} \text { years } \\
\mathbf{n}(\%)\end{array}$ & $\begin{array}{c}\text { Age } \geq 6 \mathbf{6 0} \text { years } \\
\mathbf{n}(\%)\end{array}$ & $\mathbf{P}$ \\
\hline Depression & $19(46.3)$ & $5(16.7)$ & 0.01 \\
Fatigue & $28(68.3)$ & $15(50)$ & 0.14 \\
Headache & $11(26.8)$ & $8(26.7)$ & 1.00 \\
Pyrexia & $8(19.5)$ & $2(6.7)$ & 0.17 \\
Myalgia & $20(48.8)$ & $7(23.3)$ & 0.0469 \\
Insomnia & $8(19.5)$ & $4(13.3)$ & 0.54 \\
Nausea & $11(26.8)$ & $6(20)$ & 0.58 \\
Alopecia & $7(17.1)$ & $2(6.7)$ & 0.28 \\
Arthralgia & $9(22)$ & $5(16.7)$ & 0.76 \\
Irritability & $10(24.4)$ & $0(0.00)$ & 0.0038 \\
Rigors & $5(12.2)$ & $5(16.7)$ & 0.73 \\
Pruritis & $11(26.8)$ & $7(23.3)$ & 0.79 \\
Anorexia & $6(14.6)$ & $7(23.3)$ & 0.37 \\
Dermatitis & $15(36.6)$ & $9(30)$ & 0.62 \\
Flu-like & $15(36.6)$ & $5(16.7)$ & 0.11 \\
Total events & 183 & 87 & \\
Total events per patient & 4.46 & 2.9 & 0.01 \\
\hline
\end{tabular}

TABLE 4

Mean drops in blood count with therapy

\begin{tabular}{lccc}
\hline & Age $<60$ years & Age $\geq \mathbf{6 0}$ years & $\mathbf{P}$ \\
\hline Hemoglobin, g/L & $31.6 \pm 14.4$ & $31 \pm 16.4$ & 0.92 \\
Neutrophils, $\times 10^{9} / \mathrm{L}$ & $2.0 \pm 1.7$ & $1.6 \pm 0.9$ & 0.20 \\
Platelets, $\times 10^{9} / \mathrm{L}$ & $47.0 \pm 56$ & $36 \pm 46$ & 0.40 \\
\hline
\end{tabular}

significant $(53.3 \%$ versus $34.1 \%, \mathrm{P}=0.17)$ (Table 2$)$. These rates are higher than previously reported rates of premature treatment termination. Earlier trials using standard IFN and RBV therapy have reported a $20 \%$ discontinuation rate $(4,5)$. Fried et al (19) reported 10\% discontinuation for PEG-IFN and RBV therapy and $11 \%$ discontinuation for standard IFN and RBV. In another study (2), 14\% and 13\% had discontinuation of therapy for PEG-IFN and standard IFN, respectively. These lower rates of discontinuation are likely to be a reflection of strict selection of patients who are more likely to have adhered to therapy. The results of the present study are thus more generalizable to real patient populations. All of these studies demonstrated that the most common reason for termination of therapy was adverse events, as was demonstrated in the present study.

The elderly group also had a trend toward a higher incidence of dose reduction of therapy due to all causes, which was not statistically significant (43.3\% versus $29.9 \%$ ). The elderly did have a significantly higher rate of dose reductions due to laboratory abnormalities ( $40 \%$ versus $6 \%, \mathrm{P}=0.031$ ). The rates are comparable with previously published rates. Previous studies (19) have demonstrated that dose reductions were required in $32 \%$ of patients treated with PEG-IFN and $27 \%$ in those treated with standard IFN, with laboratory abnormalities being the most common reason for dose reduction. In another study (2), dose modifications were required at a frequency of $42 \%$ for adverse events and $27 \%$ for laboratory abnormalities with PEG-IFN therapy. The rate was 34\% for adverse events and $21 \%$ for laboratory abnormalities with standard IFN (2).

Both the younger and elderly group had significant and similar drops in blood counts with therapy. However, patients 
60 years of age or older had a higher rate of grade 2 or higher cytopenias requiring frequent dose modification $(40 \%$ of elderly patients). The higher rate of grade 2 or greater cytopenias may be explained by the lower level of baseline hemoglobin, neutrophils and platelets in the elderly group. Our data show that such patients are at greater risk for cytopenias and, thus, require close monitoring and appropriate adjustment of therapy when cytopenias do occur.

The younger patients reported a higher incidence of adverse events (4.46 per patient versus 2.9 per patient). Despite this, treating physicians more often prematurely discontinued therapy in elderly patients for adverse events, $30 \%$ of elderly patients versus $12.2 \%$ of younger patients. This may be explained by the fact that the elderly patients may have had more severe adverse events or that the treating physician was more reluctant to continue therapy in an elderly patient with symptoms than in a younger patient. Despite a trend toward a higher incidence of premature treatment termination in the elderly group (53.3\% versus $34.1 \%$ ), they did not have a significantly lower rate of ETR and SVR. It is feasible that a lower rate of discontinuation of therapy in elderly patients may translate into a higher rate of ETR and SVR in this group. McHutchison et al (20) have already described that patients who receive more than $80 \%$ of the IFN regimen, more than $80 \%$ of $\mathrm{RBV}$ and more than $80 \%$ of the expected duration of therapy have a higher rate of SVR.
The present study is the first to specifically look at chronic HCV treatment response in the elderly. The rates of ETR and SVR in the control group studied are similar to previously published response rates $(2,19)$. We expected the treatment response in the elderly group to be significantly lower than that of the control group. This was based on the assumption that the elderly patients likely had HCV for a longer period of time and it is well established that the duration of the disease is a prognostic factor for response to therapy. This is evident in the fact that the elderly patients had a trend toward a higher rate of grade 3 and 4 fibrosis compared with the younger patients $(73.3 \%$ versus $53.7 \%, \mathrm{P}=0.14)$. Despite this and a documented higher rate of treatment termination, laboratory abnormalities and dose modifications in the elderly group, we found no significant difference in ETR and SVR when compared with the control group. This finding may be due to the fact that we had a small number of patients and did not have enough power to detect a difference.

Our data have demonstrated that elderly patients can be successfully treated with IFN-based therapy for HCV. They are more at risk for developing cytopenias while on treatment, thus, close monitoring of blood counts is necessary. Judicious dose modification and use of growth factors may improve treatment success. Larger studies are needed to confirm these findings and determine whether SVR differs in the elderly.

\section{REFERENCES}

1. Hepatitis C - Global prevalence (update). Wkly Epidemiol Rec 1999;74:425-7.

2. Manns MP, McHutchison JG, Gordon SC, et al. Peginterferon alfa-2b plus ribavirin compared with interferon alfa- $2 \mathrm{~b}$ plus ribavirin for initial treatment of chronic hepatitis $\mathrm{C}$ : A randomized trial. Lancet 2001;358:958-65.

3. Ferenci P, Brunner H, Nachbaur K, et al. Combination of interferon induction therapy and ribavirin in chronic hepatitis C. Hepatology 2001;34:1006-11.

4. McHutchison JG, Gordon SC, Schiff ER, et al. Interferon alfa-2b alone or in combination with ribavirin as initial treatment for chronic hepatitis C. N Engl J Med 1998;339:1485-92.

5. Poynard T, Marcellin P, Lee S, et al. Randomized trial of interferon alpha-2b plus ribavirin for 48 weeks or for 24 weeks versus interferon alpha- 2 b plus placebo for 48 weeks for treatment of chronic infection with hepatitis $\mathrm{C}$ virus. Lancet 1998;352:1426-32.

6. Management of Hepatitis C. NIH Consensus Statement 1997;15:1-41.

7. Strader DB. Understudied populations with hepatitis C. Hepatology 2002;36(Suppl 1):226-36.

8. Friedel DM, Ozick L. Hepatitis C in the Elderly. Clin Geriatr 1999;7.

9. Van-Thiel DH, Friedlander L, Caraceni P, Molley PJ, Kania RJ. Treatment of hepatitis $\mathrm{C}$ virus in elderly persons with interferon alpha. J Gerontol Med Sci 1995;50:330-3.

10. Bresci G, Del Corso L, Romanelli AM, Giuliano G, Pentimone F. The use of recombinant interferon alfa- $2 \mathrm{~b}$ in elderly patients with anti-HCV-positive chronic active hepatitis. J Am Geriatr Soc 1993;41:857-62.
11. Horiike N, Masumoto T, Nakamishi K, et al. Interferon therapy for patients more than 60 years of age with chronic hepatitis $C$. J Gastroenterol Hepatol 1995;10:246-9.

12. Alessi N, Freni MA, Spadaro A, et al. Efficacy of interferon treatment (IFN) in elderly patients with chronic hepatitis C. Infez Med 2003;11:208-12.

13. Thabut D, Le Calvez S, Thibault V, et al. Hepatitis C in 2,410 patients 65 years or older a severe and neglected curable disease. Hepatology 2003;38(Suppl 1):549A. (Abst)

14. Cawthorne CH, Rudat KR, Burton MS, et al. Limited success of $\mathrm{HCV}$ antiviral therapy in United States veterans. Am J Gastroenterol 2002;97:149-55.

15. Common Toxicity Criteria Version 2.0. Bethesda: National Cancer Institute, 1999.

16. Batts KP, Ludwig J. Chronic hepatitis. An update on terminology and reporting. Am J Surg Pathol 1995;19:1409-17.

17. Knodell RG, Ishak KG, Black WC, et al. Formulation and application of a numerical scoring system for assessing histological activity in asymptomatic chronic active hepatitis. Hepatology 1981;1:431-5.

18. Okafor O, Ojo S. A comparative analysis of six current histological classification schemes and scoring systems used in chronic hepatitis reporting. Rev Esp Patol 2004;37:269-77.

19. Fried MW, Shifman ML, Reddy KR, et al. Peginterferon alfa-2a plus ribavirin for chronic hepatitis $\mathrm{C}$ virus infection. N Engl J Med 2002;347:975-82.

20. McHutchison JG, Poynard T, Harvey J, Garaud JJ, Albrecht JK. The effect of dose reduction on sustained response in patients with chronic hepatitis $\mathrm{C}$ receiving interferon alfa- $2 \mathrm{~b}$ in combination with ribavirin. Hepatology 2000;32:223A. (Abst) 


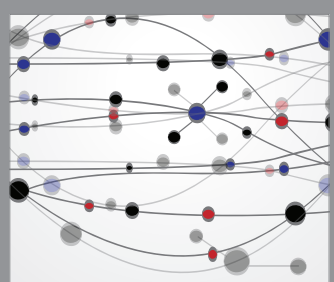

The Scientific World Journal
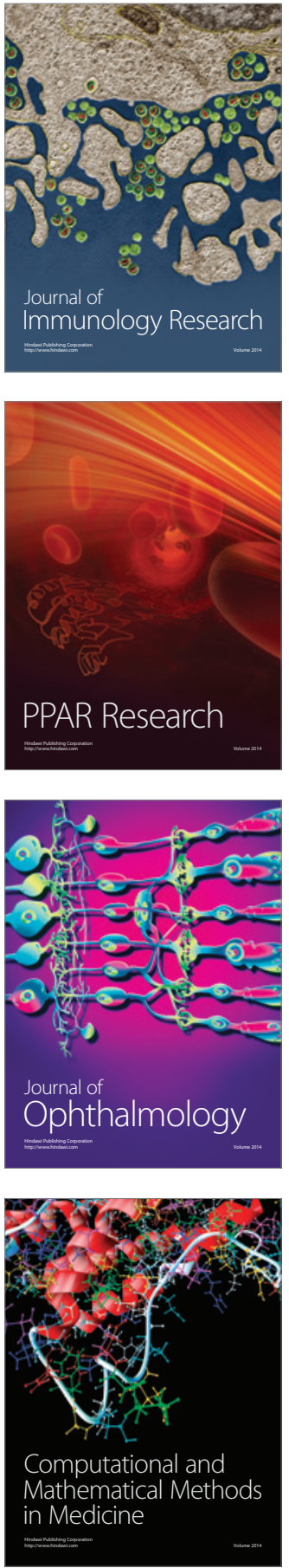

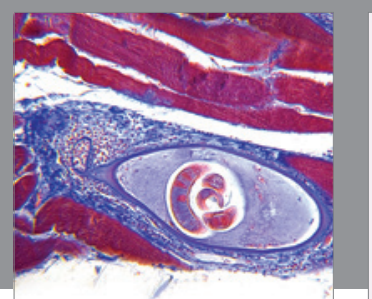

Gastroenterology Research and Practice

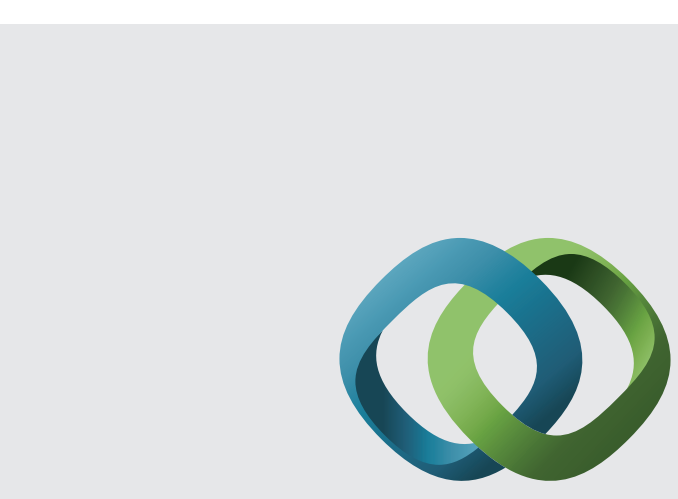

\section{Hindawi}

Submit your manuscripts at

http://www.hindawi.com
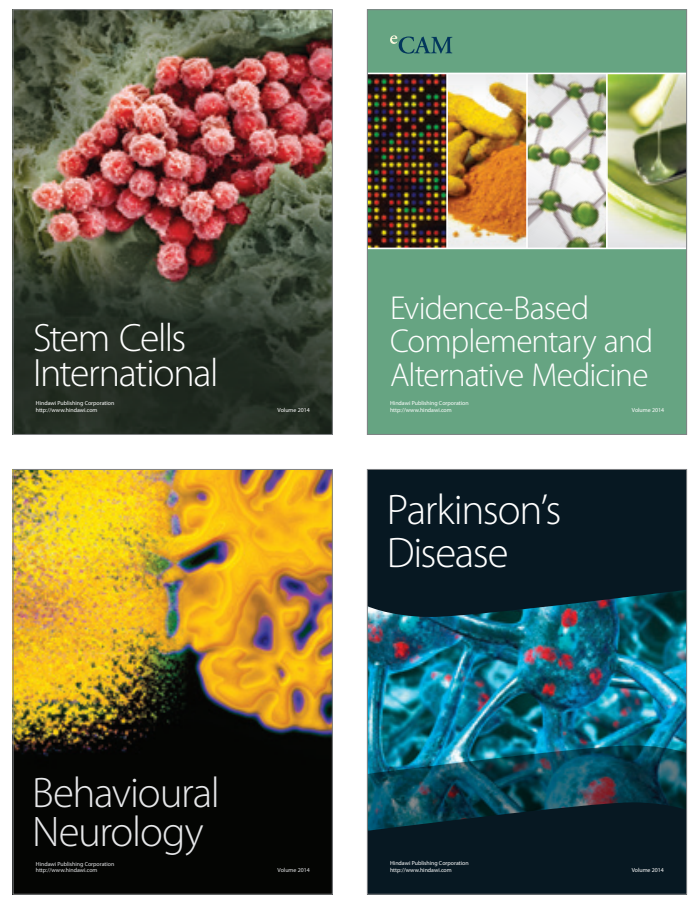
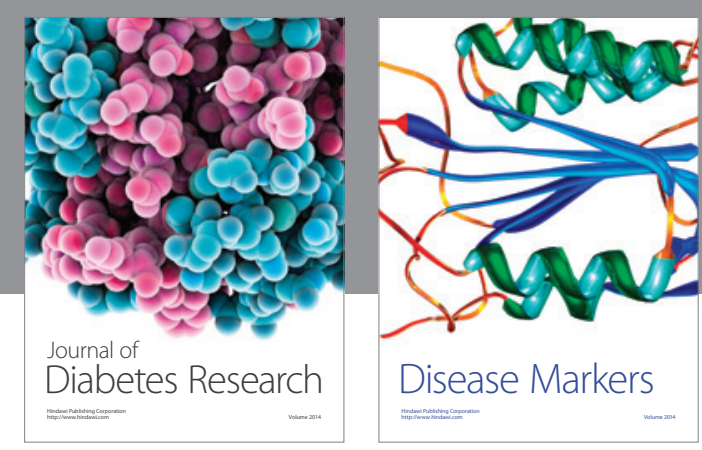

Disease Markers
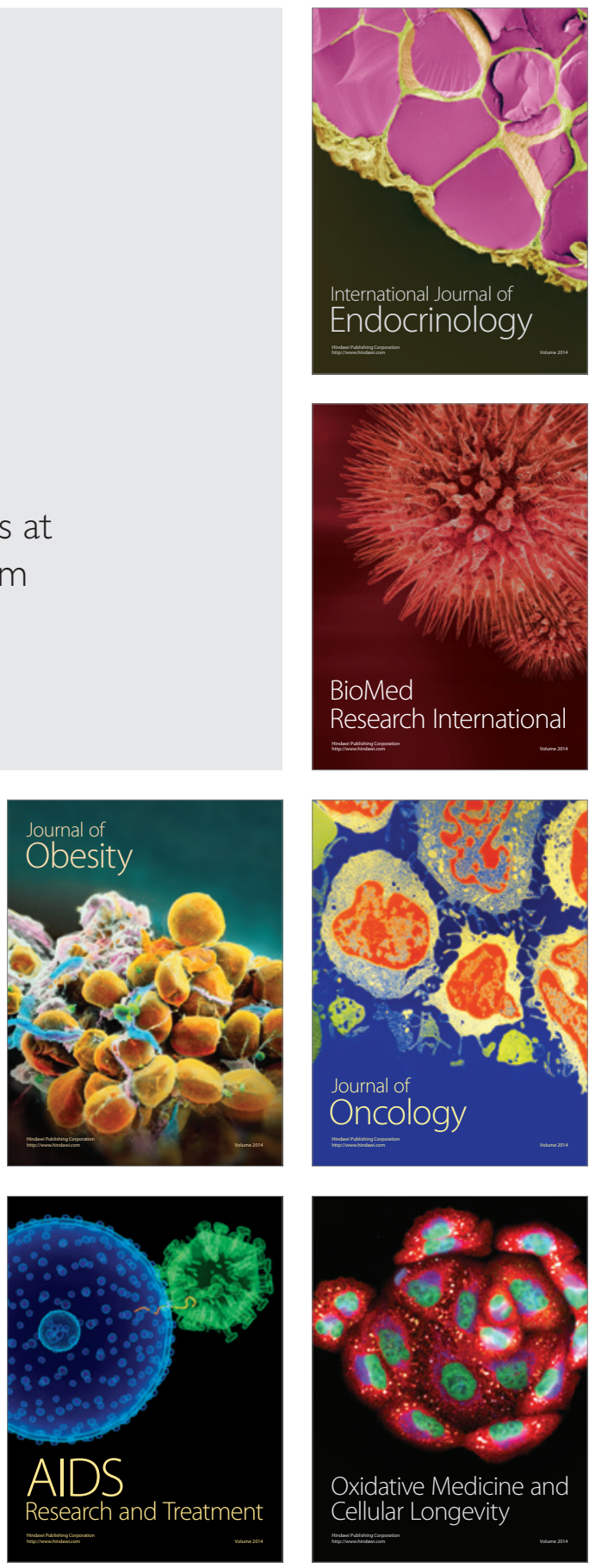